\title{
Home Away from Home: The Place of Home in Stephen Herrick's Verse Novel, A Simple Gift
}

\author{
Wendy Michaels
}

\section{The notion of 'home'}

The notion of home has been explored from a multiplicity of perspectives by sociologists, anthropologists and postcolonialists and the resulting literature demonstrates that it is possible to conceptualise home in a variety of ways. It might be construed, as Hulme (2000) suggests, as 'the "homeland" that has been left behind as well as ... the place now occupied' (p.3), or as the location in which a dwelling is situated or the space that it occupies, or even the function that it performs. Or it might encompass a city, suburb, house, room or garden, a "comfortingly bounded enclosed space, defining an "other" who is outside' (p.102) as Read (1996) proposes.

However, Hollander (1991), Read (1996), and others have argued that the notion of place, location or even house is not necessarily the same as the notion of home. Read (1996) proposes that the notion of home is 'mentally constructed' (p.101) and comprises both the physical space, whatever form that space might be, and the 'people who give it meaning' (p.125). For Read, a common aspect of people's conceptions of home is 'not as a place but an area, formed out of a particular set of social relations which happen to intersect at the particular location known as "home" (p.102). This way of conceiving home is as, Read suggests,

a way of mentally enclosing people of great importance, a reference point of widening circles of significant people and places and a means of protecting valued objects. (p.102).

Hulme (2000) suggests that in western societies, the notion of home is intimately associated with family members and with security. Rapport and Dawson (1998) also conceptualise home as the place marked by the comfort of family rituals and routines such as 'a repetition of habitual social interactions' or the 'ritual of a regularly used personal name' (p.27).

Mental constructions of home rely upon memory and imagination. For Rapport (1998) the mental construction of home relies on 'the human imagination' that is able to project the notion of home into "any "really inhabited space" (p.80), and it is this aspect, according to Hulme (2000), that allows for the conceptualization of home 'in conditions that are anything but homelike' (p.2). For Hollander (1991) sensual impressions are significant in constructing a conception of home, and Hulme (2000) points out that '[s]ounds, smells, images, the feel of different surfaces all work to weave together a notion of home that satisfies the need to feel safe and in control' (p.2). Such mental constructions of home are intimately connected with the notion of identity, or as James (1998) argues, home is ultimately the conceptual space where 'one best knows oneself' (p.142).

\section{Home and homelessness}

What then, does it mean to be homeless? Hulme (2000) points to the polysemic nature of the word and the ways in which various researchers and government documents have conceptualized youth homelessness. She outlines some of the issues commonly associated with youth homelessness including lack of physical shelter, lack of a family, absence of a place to live (p.4) and being excluded from society (p.5). While homelessness is a particular focus of contemporary society, the homeless have been, as Allen (2001) points out, the subject of literary works since at least the time of the Middle Ages. Allen identifies two contrasting approaches to representing the homeless in literature. On the one hand, there may be 'glorification of the freedom and adventure associated with life on the road' and on the other hand there may be 'condemnation of the degradation and abjection of those who have been economically or socially displaced' (p.1). Such glorification is exemplified in Chaucer's Canterbury Tales where the pilgrims, having left their own homes, are journeying to a spiritual home in Canterbury Cathedral.

The representation of the homeless as socially displaced is exemplified in classic texts such as Felice Holman's Slake's Limbo or Charles Taylor's Wild Children as well as in recent Australian young adult novels such as Libby Hathorn's Feral Kid, Deborah Ellis's Parvana's Journey and Scott Monk's Raw. In Deborah Ellis's work, Parvana is homeless in Afghanistan through no fault of her own, while Monk's character, Brett Dalton is 'busted' for a criminal action and removed from his home to a prison farm as a consequence of his criminal actions. According to Scutter (1999) '[b]ooks for children and teenagers have been almost definitively concerned with notions of 
home and homecoming' (p.150). She suggests that ' $[w]$ hile the family home is usually the crucial space in children's literature, and "housekeeping" and "homecoming" are abiding preoccupations, occasionally other spaces take centre stage' (p.161). These other spaces might include the home-away-from-home of 'the secret garden in its various guises' (Scutter 1999. p.162) that offer sanctuary.

As Scutter (19990 points out, '[f]ictions set up a kind of cartography' (p.162) - a mapping of the social spaces in which people live and work and play. Mapping involves the positioning of people and places in space and it is particularly appropriate that issues of homes and homelessness should be represented in verse which, as Mallam and McGillis (2003) argue, 'occupies a spatial dimension' and like the visual arts depends upon an 'understanding of spatiality' (p.7). They further suggest that the 'Australian verse novel ... revels in the hybrid nature of its literary form and literary precedents' (p.7).

\section{Genre blurring: the verse novel}

The word 'novel', used to describe works of prose fiction since the seventeenth century, has recently undergone a transformation of meaning through contemporary publications of both adult and young adult verse novels. Crowe (2002) argues that many writers 'have stretchedand broken-traditional boundaries of literature' not only for adults but also for children and adolescents (p.116). It is through the pushing of such boundaries, Crowe argues, that 'what we today know as young adult literature' (p.116) has been shaped and formed. While Scutter (1999) suggests that the "labelling or classification of certain books as "young adult" can be seen as a cynical marketing ploy' (p.4) there is also a case to be made for the writer's role in steering a literary form or genre in new directions by challenging existing writing or publishing conventions. Crowe (2002), for instance, asserts that the 1998 winner of the Newberry Medal, Karen Hesse's Out of the Dust (1997), did just this in 'effectively challenging the literary tradition that defines novels as prose narratives' (p.117). The arrival of Herrick's first verse novel in the Australian young adult publishing scene in 1996 just predates this American work and he can be seen, therefore, as having already pushed the boundaries of the YA novel form. The title (Love Ghosts and Nose Hair: A Verse
Novel for Young Adults) itself, signals something about the newness of the form.

But this new form has not arrived on the publishing scene without a genealogy. Turton (1999), for instance, identifies the progenitors of the contemporary verse novel in early ballads and folklore that 'told a story ... rhythmically ... [and] dramatically' (p.4) while Pollnitz (2002) identifies the first verse novel as Pushkin's 1833 tale, Eugene Onegin, which he argues was, itself, influenced by Byron and his mode of telling a story (p.62). The Reading Time reviewer of Herrick's, A Simple Gift (EC. p.14) also identifies in that verse novel "echoes of old stories, legends and literary allusions'. Apart from these earlier traditions of narrative verse, Turton (1999) argues that a specifically Australian progenitor of the YA verse novel can be identified in Jenny Boult's poetry collection, About Auntie Rosie, (1988), which Saxby (1993) describes as 'a family album' in which the poems 'speak through the voices of a wide assortment of family members' (p.635). Saxby applauds the way it "captures the nuances of everyday suburban life' in an 'e e cummings style of uncapitalised, unpunctuated verse' that incorporates 'the idiom of young people and of everyday dialogue ... without losing dramatic intensity' (p.636) in the story it tells.

\section{Steven Herrick's YA verse novels}

Herrick produced Australia's first YA verse novels, including Love, ghosts and nose hair: A verse novel for young adults(1996); A place like this (1998); The spangled drongo: A verse novel (1999); A simple gift (2000); and Love poems and leg spinners: A month in the life of class $5 B$ (2001), Three of these (Love, ghosts and nose hair, $A$ place like this, and $A$ simple gift), have been short-listed for the Children's Book of the Year Award in 1997, 1999 and 2001, although no verse novel has yet won the award. Turton suggests that the success of verse novels such as Herrick's derives from various features, not least of which is the way that 'like traditional ballads ... [they] leave the reader to flesh out mundane details drawing them emotionally into the storymaking themselves' (1999, p.7). The verse form places the emphasis on emotion rather than simply action. The play with dramatic monologue allows the writer to reveal, economically 
through image and word play, the interiority of the characters while dramatically representing the events through direct address to the reader. Turton argues that verse is able to produce a 'concentration of emotion ...[derived] from the everyday' (p.7) and she identifies 'the apparent simplicity of the language, the sparseness of the text, even the amount of white space on the page ... and the immediacy of emotional involvement' (p.7) as the strengths of this narrative form. She records the following comments made by Herrick's editor to support his viewpoint:

I was amazed how so few words could bring out so much emotion. ... Every word counts and it has an immediacy that prose fiction wouldn't have. (p.5)

A Simple Gift is a YA Australian verse novel that recounts the story of sixteen-year-old Billy who runs away from home, hitching a ride on an empty goods train, and on reaching the country town of Bendarat makes a new home in a disused railway carriage, where he encounters Old Bill, a drunken hobo who periodically sleeps in the adjacent carriage. The third main character in the tale's triangle is Caitlin, a seventeen-year old school-girl whom Billy encounters working in McDonalds. The story is told in a series of dramatic monologues implicitly addressed to the reader, each from the perspective of one of the three main characters (with one monologue in the voice of Ernie, the train driver, that is addressed to Billy). Billy has sixty-one of these monologues, Caitlin, thirty-two and Old Bill has twenty-one so that the dominant voice is Billy's and it is his story, primarily, that we follow to its resolution. But Billy's story is intimately interwoven with both Caitlin's story and Old Bill's story so that the resolution of Billy's problem also engages these two characters. All the other characters (either living or deceased) are evoked and mediated through the voice of these main characters as the narrative unfolds through the juxtaposed dramatic monologues.

Pollnitz (2002) describes this novel thus: Bad fathers, broken homes and dysfunctional
families are transformed and reformed in a new
triangle of trust and support, and Billy, convinced in part by the librarian, is making his way out of

vagrancy and back into the mainstream. (p.65)

While this is a somewhat sweeping statement of the scenario (Billy's father is not transformed or reformed, and the librarian is more of a catalyst than an agent in Billy's own transformation), Pollnitz's identification of 'home' as a central concern of the novel is certainly correct. This is represented visually in the juxtaposition of the key to the home with the images of the railway lines and siding: the notions of home and homelessness are evoked in the black and white photographs that preface each chapter and are replicated on the book cover. The novel offers representations of three key homes - those of the three main characters, Billy, Caitlin and Old Bill. Billy's home is located in a large city while the other two are situated in a large country town. The readers are taken into these homes through the descriptions of the characters and the memories that are recalled of events and relationships. In addition, we see into the home-awayfrom-home that Billy and Old Bill inhabit while the wounds inflicted in their homes heal; and into Caitlin's sterile, materialistic home that fails to nurture her emotionally.

\section{Billy's home}

Billy's motherless home in Longlands Road is located in an unnamed western suburb of a big city: Sydney is suggested by the reference to the Great Western Highway, although Herrick does not specifically name the city. Billy has ascribed the term 'Nowheresville' to the place and uses words with highly charged negative connotations to describe his street and his suburb - this 'damn place' and to evoke a real sense of his hatred of the 'dump' that he sees as 'rundown and beat'. This impression is particularly highlighted in the way in which Herrick uses personification of the stones that Billy is throwing onto 'each deadbeat no-hoper/shithole lonely downtrodden house' which, Billy says, 'protest/at being left' behind as he escapes.

Billy's feelings about his street and suburb are paralleled with his hatred of the school he attends. The school is evoked through images of the litter in the playground ('blowing potato crisp wrappers/across the oval'), the polluting smoke blowing from the Principal's car exhaust, 
the impersonal, almost prison-like image of 'Room 421' where students are learning 'about the geography of Japan', the connotations of the teacher's name ('Cheetam') and Billy's own graffiti on the window in 'K-Mart Red lipstick' where the overtly scatological ('get/well and truly stuffed') is neatly juxtaposed with the unstated but implied ('Luckett/rhymes with ...').

These descriptions offered to the reader by Billy in the first pages are also reinforced by later accounts from Billy's memory of events relating to his father in this house. The first memory is stimulated by the kindness of Ernie, the train-driver who offers him shelter in the guard van of the train to Bendarat. Billy recounts the incident where his father assaulted him ('one hard backhander/ across the face') after he had broken the bedroom window with a ball. Billy presents this as an act of rage on the father's part that has had a profound effect on him-a boy of ten-but which seems to have gone unnoticed by his father. Herrick juxtaposes Billy's bleeding face ('I could taste it dribbling out') with the father's apparent unconcern 'in front of the television/as if nothing/had happened'. The father's words, albeit mediated through Billy's narration ('no more sport/no more forever'), and his action of kicking Billy's soccer ball into the bushes, are experienced by Billy as destructive of his 'sporting childhood'. Billy's mental construction of his home is imbued with his feelings of oppression by his father, whom he remembers as 'attached to his lounge/his television/and his smelly unkept house'. He constructs his 'bastard' father as associated with alcohol and drunkenness ('He' d be sober because I stole/his beer/his champagne'), rejection and physical abuse. He recalls his father chasing him out of the house with a strap and his hiding in a 'neighbour' s/chookshed' until nightfall when his father would be asleep and he would be able to climb through his bedroom window. The kindness of the neighbour in leaving him a bowl of soup for his dinner is contrasted with the brutality of his father in his own home.

\section{Leaving Home}

Billy's decision to leave home and become a vagrant is presented as understandable in this context. Billy's exit takes him not only away from the dump of his home, but also away from the abusive father. His leaving home begins with an unsuccessful attempt to hitchhike on the Great Western Highway that sees him resort to riding a freight train where he encounters a surrogate father figure, Ernie the train driver, who offers him shelter, succour and advice. Ernie, having discovered Billy hiding in his speedboat on board the otherwise empty train takes Billy into the warmth of the Guard's van where he provides warmth and food. We actually hear Ernie's voice in one monologue and although, like Billy's father, he is associated with drinking excessive quantities of alcohol, there is a sense that he does not do so in circumstances where it affects others but rather as an escape into another world-in the boat on the lake. For Billy, Ernie becomes a benchmark for his later understanding of the drunken hobo Old Bill, who also uses alcohol to deaden his pain.

However, Billy's decision to leave home is taken with some misgivings. Billy confesses his regret at having to leave Bunkbrain, the dog that 'doesn't deserve to stay/in this dump'. Billy's affection for the dog is captured in images of him 'scratch[ing] behind his ears' and 'kiss[ing] the soft hair/on his head' and in his direct address to Bunkbrain - 'I'll miss you dog'. But this is balanced with his realistic assessment that 'you don't get rides/with a dog'.

The other regret that Billy articulates is leaving the haven that Westfield Creek has provided for him from the traumas of his home-life and from the frustrating boredom of his school-life. In this evocation of a secret garden he has been able to dream. A sense of the peace of this sanctuary is captured in images of the natural world that have Romantic echoes such as the 'flow of clear water/ over the rocks', the 'wattles on the bank', 'the lizards sunbaking', the 'silver-eyes and currawongs' and the 'kookaburras laughing'. The joy and playfulness that he has experienced at Westfield Creek is highlighted in the image of 'kids swinging on the rope/and dropping into the bracing flow'. This place also has become for Billy his 'favourite classroom'. Despite his admitting to the theft of books from the 'Megalong Bookshop', we are inclined to forgive him the misdemeanor since he has evidently put the stolen books to good purpose: 
I failed every Year 10 subject

Except English.

I can read.

I can dream.

I know about the world.

I learnt all I need to know

In books on the banks

Of Westfield Creek,

My favourite classroom.

Despite these two regrets, Billy sets off on his journey to homelessness with no real plans other than 'heading west'.

\section{Old Bill's Home}

Old Bill's home, like Caitlin's, is located in the town of Bendarat—a large regional city 'miles from home/miles from school' where Billy alights from the freight train on Ernie's advice. While the name, Bendarat, has echoes of Bendigo, a Victorian goldfields town, the description 'once/the railway hub of the south-west' suggests an old town close to main agricultural and pastoral regions where 'cross-country trains' were loaded 'with wheat and wool/and fruit from the orchards'. As a location, Bendarat is presented as a harmonious blend of the natural and the built environment. It is an old town and like Old Bill it is not represented in a sentimentalised, idealized way. Bendarat is not simply a Garden of Eden or paradisical place. Rather it is depicted as a place that has, like Old Bill himself, seen better times. It is a place that was once the hub of a thriving town but is now almost past its prime. However, Bendarat, despite its problems, is a place where the 'sun is shining'. Billy's first impressions of Bendarat are of an old, once rich but now struggling town with 'stone buildings/and wide streets/and cast-iron street lamps' with 'SALE' signs in every shop. Old Bill's description of the 'parks with trees/and fountains' where 'people nod and say hello' is paralleled with Billy's description of the gardens where birds (albeit 'pigeons') wait for 'some crumbs' and 'a couple kissing on a blanket' provide 'lunchtime entertainment' evoking a sense of freedom and happiness.

Old Bill's home reflects this duality of Bendarat. Situated in Wellington Road, it was once the locus of what appears to have been a happy family, despite the regrets that Old Bill expresses about his own previous focus on his work rather than his family, but is now the source of painful memories about the deaths of the wife and daughter whom he clearly loved.

We learn about his home through his own recounting of his memories of the place, through Billy's account and Caitlin's description after they visit it, as well as through Billy's own recounts of the memories that Old Bill has shared with him. We gain the impression of a 'beautiful white timber house' - old, solid and spacious—with a wide verandah and 'a huge backyard' filled with trees, 'wattles and firs', that Bill had planted, the shed he had built and a patch of lawn. The trees are filled with singing birds that flock to the 'homemade bird feeder'. Associated with this home, before the accident, are family activities, captured in the image of summer evenings spent in 'sipping wine and cooking steak' on the BBQ, the hopes and dreams of Jessie who wanted to 'learn to dive/among the fish in the warm/tropical waters thousands of miles away', and the playful highjinks of Jerry, the 'little cockerspaniel/who loved sausages'.

Bill's house is not without material possessions such as television, stereo, fridge, curtains 'with seashell patterns/ in vivid blue' and 'solid old timber' furniture, but the images associated with these are particularly homelyevoking a sense of love and solidity. Billy describes the kitchen as 'a place where someone/had enjoyed cooking' and the 'height markings' on a door frame include the voice of the deceased Jessie: 'I've grown 13 centimetres in 2 years,/lots more than Dad'.

For Old Bill, this once happy home is imbued with the memories of the deaths and his signing of the form that allowed the doctors in the hospital to 'switch off the machine'. This memory has haunted him in the intervening years and is closely connected with his home. He recounts that, after Jessie died, he 'went home and/took to the tree with an axe'. And as he remembers this traumatic event he also recalls, with regret, arriving late home from work with Jessie waiting up to see her father or being too busy with work to eat breakfast with his wife and daughter. 


\begin{abstract}
Abandoning Home
Old Bill's desertion of his family home is not a calculated leaving like Billy's, but rather an erratic, alcohol-induced attempt to avoid dealing with his painful ghosts. These ghosts are the two deaths of his daughter, Jessie, and his wife (whose name we don't learn) on the same day (March 4) one year apart. Jessie's death, after the turning off of a life-support machine, was the result of an accident in the yard of the family home, when Jessie fell out of a tree. Old Bill explains to us his struggle to understand the events leading to both Jessie's death and his wife's death, also occasioned by a tree, following a car accident when she was 'driving drunk' following her inability to deal with their daughter's death. He expresses feelings of guilt and powerlessness that all his knowledge of the Law, his money and 'all that training/couldn't stop a young/child from/falling out of a tree'. He describes his abandonment of the house that had been their home thus:
\end{abstract}

\section{I closed the door}

To our house,

Left everything as it was

And walked away.

What he discovers, however, is that despite deserting the house, the memories of the place and all that happened in it, his feelings of guilt and his sense of powerlessness travel with him and he finds his only escape through alcohol - until Billy intrudes into his life in his temporary home in the Bendarat Freight Yard.

\section{Home Away From Home}

While for Old Bill, Bendarat has been a source of grief and loss, the town offers Billy the kinds of nurturing that he has previously lacked: food ('apple and pear orchards'), comfort ('a warm McDonalds'), shelter ('luxury train accommodation'), and intellectual succour ('friendly librarian'). Gradually it also offers him a new home, 'Carriage 1864', friendship and support in the figure of Irene, work and income at the Golden Crest Cannery, love and acceptance with Caitlin and Old Bill and eventually, 'the simple gift' of a home, albeit a temporary one.

Both Billy and Old Bill take up residence in their home away from home in disused railway carriages in the
Bendarat siding. Old Bill has been there, on and off, since 1994, a date that asks us to believe that some years have passed since the terrible events that he wants to blot out of his memory. He has been permitted to stay there by the authorities since he doesn't 'make much noise' and keeps the place clean, although Billy does note the 'smell of old socks/and alcohol' when he first visits Old Bill.

Billy's home away from home, Carriage 1864, is next door to Old Bill's. Billy describes it as 'painted red and yellow' and

$$
\begin{aligned}
& \text {... waiting to be sold } \\
& \text { and turned into } \\
& \text { fancy Bed \& Breakfast Accommodation } \\
& \text { or maybe used as someone's chookshed. }
\end{aligned}
$$

In this space he creates a new home that is 'quiet, so quiet', 'surprisingly warm' and provides a sanctuary (a secret garden), 'a warm, safe little cave', as Caitlin describes it. The space is furnished with 'a long bench' that is 'old and well made' and comfortable, and which Billy uses as a bed. The images associated with this home away from home ('bright sunshine' and 'laughing') highlight the sense of happiness that emanates from this safe place, an impression reinforced by Caitlin's description when she comes to visit:

\section{It was like stepping \\ Into heaven \\ All that light, \\ With Billy smiling \\ On the seat, \\ |Proud of what he'd created.}

This refuge gives order, meaning and routine to Billy's life. We see this in the way in which he organizes the space, with his sleeping bag and his rucksack used as a pillow on one of the leather seats and the stacking of his books on the other, as well as in the way in which he identifies himself on the 'business card':

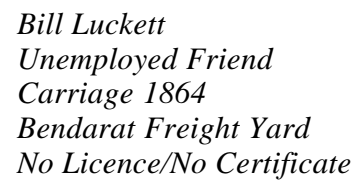


Billy and Old Bill, residing in adjacent carriages, visit each other almost like a father and son might go into each other's bedrooms, sheds or private spaces. Their growing reciprocal relationship is based on unconditional acceptance of each other's situation. This is highlighted in the image of the bowl of Weet-Bix that Billy takes to Old Bill and which initially elicits his 'Piss off son' response and his later reciprocal 'breakfast bowl' brought to Billy which is associated with images of joyful sharing in their 'long and loud' laughter. This home that Billy has named 'Motel Bendarat' is the 'Bendarat Hilton' to Old Bill. Both these titles suggest that the two characters see them as a home away from home-a temporary place of abode in which they share laughter, compassion, understanding. Indeed, for both characters it is, indeed, a temporary place of abode, but one that restores for each his sense of self and sets each of them on the road to recovery.

The location of their temporary homes in the Bendarat Freight Yard allows them to access the facilities that the town has to offer. The Bendarat River and the homely functions it comes to serve for both Billy and Old Bill, and even to some extent, Caitlin, creates an echo of the significance of Westfield Creek for Billy's sense of self. Imagery of birds ('ducks gliding by' and 'ibis on the opposite bank'), fresh water and 'the sun sparkl[ing] on the water' create a paradisical sense of the river that comes to serve Billy and Old Bill as the 'Bendarat Laundry'. The river with its 'cold, clear/and deep' 'whirlpools' and bubbles enables Billy to 'wash the world away' providing a restorative and cleansing place for both Billy and Old Bill. It is also the place associated with picnics in which Billy and Caitlin, and Billy and Old Bill share food, relax and enjoy each other's company. Importantly, it is the place where Old Bill finally tells Billy about his past, his job and the 'Trust Account' that provides his present source of income, and he admits to Billy that 'it's taking a while/for him to get used to/the taste of being sober'. The river symbolizes a restorative force for both Billy and Old Bill.

Thus Bendarat is established as a town that, ironically, looks after its residents-even its vagrants. Food is provided for Billy at McDonalds-a place for "eating out' where 'it's quiet and warm' and there is a free newspaper. Billy's scavenging of 'the burger/and the fries' and the dessert from the half empty plates of departing customers and his 'healthy breakfast of fruit' pinched from the Golden Crest Cannery Farm reinforce this image of Bendarat as a provider and nurturer. Similarly, the image of the caring town is emphasised through Billy's interaction with the public librarian, Irene. In this 'good library', with its 'lounges soft and comfortable' Irene adopts a supportive, maternal role. In sharing her view of Lord of The Flies ('It was my favourite when I was young'), she establishes a rapport that is built up throughout the novel. At the end, it is Irene who provides the practical assistance of the TAFE Handbook and 'an application form/for government study assistance'.

The Golden Crest Cannery with its 'tomato line' also offers a different kind of sustenance to the two 'hobos'. There is no sense of a sentimentalized notion of work as ennobling. Rather it is simply presented as a pragmatic necessity and a means that Herrick uses to establish the reciprocal relationship that is to develop between the two homeless characters. Billy's evocation of the 'overripe mess' of the fruit with its 'black fetid bits' and 'the noise, the smell' that 'overpowers everything' except the need to earn money is juxtaposed with Old Bill's response to the situation in which he finds himself accompanying Billy. These juxtaposed accounts allow us to see the way in which their developing reciprocal relationship is helping both on a path to recovery. Old Bill confesses that he is 'not drinking so much' and 'can't smoke in the Cannery', while Billy resists the temptation to steal from the jeweller whose acceptance of him as a customer, despite his 'smelling of overripe tomatoes' helps towards restoring his own sense of self. Despite the awfulness of the place, both characters find human compassion, understanding and acceptance in the work.

\section{Caitlin Holmes}

The idea of what constitutes a home is brought into sharp focus through the contrasting character of Caitlin whose surname, Holmes, provides a neat homophone for one of the central ideas of the novel. Just as Billy creates a home for himself from simple objects and strong personal 
relationships, so Caitlin learns the importance of the nonmaterial through her association with Billy and Old Bill. Her home is the antithesis of the other homes in the story in almost every possible way. We learn about her home and what it means to her both from her monologues and from the descriptions of Billy and Old Bill after they have been there for dinner. Caitlin confesses to 'being rich' and having 'a dad who/spoils [her]'. She itemizes the material possessions that are lavished upon her including 'more clothes/than I'll ever wear', 'a TV and a CD player', 'large desk with a computer', all of which is summed up by her as 'stuff' that her parents think she wants or needs. In her own estimation, what she really needs is 'not able to be bought/in any damn store'.

To Caitlin, her house is a 'big ugly five-bedroom/million dollar brick box'. Caitlin describes her home in images associated with conventional notions of luxury lifestyles: a 'full [bath] tub' for relaxing in, expensive wine from a cellar and well-cooked food, and these are reinforced by Old Bill's description of the place. He locates it for the reader in the 'rich streets of town', with their neat gardens, high fences, solid gates and double garages. Despite Caitlin's perception of her home as 'too clean' and somewhat sterile, for Old Bill, her invitation to dinner and her hospitality constitute a 'simple gift' that prepares us for his later reciprocal act.

It is in Caitlin's single bed with its 'crisp white sheets' and 'oversized doona' that the two young characters first make love after Old Bill has respectfully retreated from the dinner party. For Billy the experience is captured in images associated with the river-'clear waters', 'the gentle tide', and 'beautiful/phosphorescent bubbles of light'. Through their love-making they have created a 'special world', another kind of secret garden that has echoes of Westfield Creek and the Bendarat River, while for Caitlin, the experience is an entry into an another sphere that enables her to forget her 'other life' of material possessions.

\section{Homelessness}

However, Billy's carriage residence does not constitute a home in terms of the requirements of the authorities. $\mathrm{He}$ is not 'living with a responsible adult/in a normal house'.
His apparent homelessness is brought to the attention of the police on Main Street and this constitutes the climax that precipitates the resolution of this novel. Billy, in answering the questions put to him by the policemen about his age, workplace and place of abode, resorts to telling a number of lies. He perceives that the police do not believe his untruths, but the older policeman calls his bluff by presenting him with the card of 'Welfare Officer: Brent Stevens', demanding to meet Billy at his office the next day at $4 \mathrm{pm}$, and issuing this threat:

... if I didn't show
well, fine, I'd moved on,
but if he saw me
in town again
and I hadn't shown,
he'd ask more questions,
and this time he'd want some
answers.

This, ironically, places Billy in a situation of emotional and moral conflict at either having to leave what he describes to Old Bill as 'the only town/I've ever wanted to call home' or finding some legitimate way of remaining. The consequence, not articulated but implied, is a return to the home with the abusive father that he has sought to escape.

Old Bill's response resolves the conflict for the three main characters. But for Old Bill, determining to make the 'simple gift' is not a simple decision. Old Bill himself tells us that it was 'so obvious/and simple/and so unbearably painful'. Assistance in making this decision comes with a memory of his home and his daughter and the wounded bird. He tells us:
I thought of Jessie
helping that bird
and how, after it left,
Jessie turned to me
and said that
when she grew up
she wanted to be a vet, she wanted to heal animals and to help people. 
This memory firms his decision and he goes back to his house and mows the lawn before going to the Salvation Army shop to purchase clothes for the delivery of the 'simple gift'. Old Bill, drawing on his understanding of the Law, and his knowledge of 'stupid rules and regulations' and the legal rights of a sixteen-year-old boy, 'could come up/with a solution' for Billy's predicament. Ironically at the same time he comes to understand that while that knowledge could not prevent the terrible accidents of his wife and daughter it 'was finally worth something'. His sense of self is also restored and affirmed through his gift.

\section{Homecoming}

The resolution of the novel sees Billy provided with a home that is more than simply temporary, Old Billy leaving home with a productive purpose, and Caitlin restoring her relationship with parents and bringing into her own home the non-material qualities that she previously craved, and had found in her relationships with Billy and Old Bill: honesty and trust.

For Old Bill, the sky has become the roof over his head as he sets off with his swag to take the ghosts of his own house with him on the 'trip to the ocean' that he had wanted to take his daughter, Jessie, on so many years ago. As he does so, he feels confident that Billy was caring for his home until he returned. This is a careful and deliberate leaving — not an abandoning as he had previously done after 'that March day' - with a certainty of returning healed. This is particularly suggested by Billy's image of him looking at the sky 'like he was praying'.

For Billy, the home given to him by Old Bill not only allows him to satisfy the police officer and welfare worker, but also allows him to put his life in perspective. He has established a stable relationship with Caitlin and he anticipates that he might even 'go back to school'. Hovering in the background, Irene the librarian seems to have adopted a surrogate mother role and despite the departure of the surrogate father, Old Bill, there is a sense of someone watching over Billy. Billy's understanding of this home as temporarily borrowed is evident in his resolve to 'tread lightly/with respect' and his determination to visit his carriage each week so that he will 'never forget this home/by the railway tracks' that has nurtured him.
For Caitlin, the gift of the house to Billy strengthens her resolve to establish a more honest relationship with her parents in her own home:

\section{... I'll walk into Mum and Dad's questions and I'll answer them truthfully.}

The home comes to represent for her all that she was previously longing for in the 'richest house in Bendarat'.

\section{Place, Memory, Identity}

This novel makes a strong statement about the nature of home and the mental construction of home as a place of peace, succour and security. Such a construction is not dependent upon location, space, or material possessions, nor is it solely connected with family. None of the three homes initially offer these qualities to the characters although for different reasons: conspicuous consumption in Caitlin's, abusive violence in Billy's and memories of death in Old Bill's. However, the temporary home of the railway carriages, in conjunction with the surrounding facilities of the town offer all characters a home-awayfrom-home that is restorative.

Crucial to this restoration are the reciprocal relationships that the characters construct with one another. Home, as Herrick represents it, is more concerned with the actions and people within the shared space-the respect and caring that they show for each other, the ways in which they use this caring to build an atmosphere and ambience that is homely. And it is this interaction that builds new memories for all three-memories that allow them to construct a new home from their imaginations, and wipe out the memories of the painful ghosts that had previously haunted them. Through this process, they come to new understandings about themselves. While it has been the nature of their homes and the events that have occurred there that have driven all the characters away from their homes, it is also the need for home that is finally resolved for all of them. The verse novel is a powerful way to explore these issues about mental constructions based on memories since it works through sensuous imagery that allows us access to the interior feelings and thoughts of each character and the opportunity to share their mental and emotional journeys to new identities. 


\section{REFERENCES}

Allen, John (2001) 'How the other half lives: representations of homelessness in American literature'. Dissertation Abstract accessed at http://www.uwm.edu/People/jpnallen/ abstract.html

Boult, Jenny (1988) About Auntie Rosie. Adelaide, Omnibus/Puffin.

Chaucer, Geoffrey (1992) The Canterbury Tales, trans. Nevill Coghill. London, Cresset Press.

Crowe, Chris (2002) 'Young Adult literature' The English Journal July: 116-118.

EC (2001) 'Review: Steven Herrick, The Simple Gift', Reading Time 44, 4, 14.

Ellis, Deborah. (2000/2002) Parvana's Journey. Sydney, Allen and Unwin.

Herrick, Steven (1996) Love, Ghosts and Nosehair: A Verse Novel for Young Adults. St Lucia, University of Queensland Press

Herrick, Steven, (1998) A Place Like This. St Lucia, University of Queensland Press

Herrick, Steven, (1999) The Spangled Drongo: A Verse Novel. St Lucia, University of Queensland Press

Herrick, Steven (2000) A Simple Gift. St Lucia, University of Queensland Press

Herrick, Steven, (2001) Love Poems and Leg Spinners: a Month in the Life of Class 5B. St Lucia, University of Queensland Press

Hesse, Karen (1997) Out of the Dust. New York, Scholastic.

Hollander, J. (1991) 'It all depends', Social Research 58, 1: 31-49.

Hulme, Alana. (2000) 'Borders and spaces: Experiences of home and homelessness for young, homeless, same-sex attracted women.' Paper presented at Young Women 2000 Conference: It's a jungle out there!
Mallan, Kerry \& McGillis, Roderick (2003) 'Textual aporias: Exploring the perplexities of form and absence in Australian verse novels' http://www.the-looking-glass.net/ v7i2/academy.html

Monk, Scott (1998) Raw. Sydney, Random House.

Pollnitz, Christopher (2002) 'Young adult verse novels in Australia' mETAphor 4: 62-67

Pushkin, Alexander (1992) Eugene Onegin, trans. A.D.P. Briggs. Cambridge, Cambridge University Press.

Rapport, N. \& Dawson, A. (1998) Migrants of Identity: Perceptions of Home in a World of Movement. Oxford, Berg.

Read, Peter. (1996) Returning to Nothing: The Meaning of Lost Places. Cambridge, University of Cambridge Press.

Saxby, Maurice (1993) The Proof of the Puddin': Australian Children's Literature 1970-1990. Sydney, Ashton Scholastic.

Scutter, Heather (1999) Displaced Fictions: Contemporary Australian Fiction for Teenagers and Young Adults. Melbourne, Melbourne University Press.

Turton, Rayma (1999) 'From literary ballad to verse novel: narrative poetry in the contemporary scene.' The Literature Base 10, 4: 4-14.

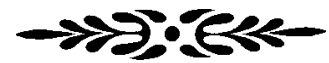

\section{BIOGRAPHICAL NOTE}

Dr Wendy Michaels lectures in the School of Humanities at the University of Newcastle. She teaches courses in Australian Children's Literature, Performance Histories and Creative Writing. She writes poetry, plays and stories for children. Her publications include a picture book, Secret Smiles. Her current research interests are in new directions in adolescent fiction, the developing genre of young adult verse novels and the evolving 'genre' of picture books. 